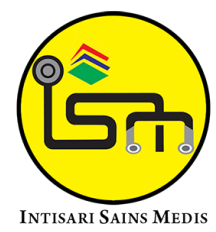

Published by Intisari Sains Medis

\title{
Perbedaan ekspresi Vascular Endothelial Growth Factor (VEGF) pada meningioma risiko rendah dan risiko tinggi di RSUP Sanglah, Bali, Indonesia
}

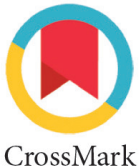

CrossMark

Ivana Juliarty Sitanggang ${ }^{1 *}$, Ni Putu Sriwidyani', I Wayan Juli Sumadi', I Gusti Ayu Sri Mahendra Dewi', Luh Putu lin Indrayani Maker', I Made Muliarta ${ }^{2}$

\section{ABSTRACT}

Background: Vascular Endothelial Growth Factor (VEGF) is an angiogenic factor that plays an important role in tumor angiogenesis. VEGF in meningioma is up-regulated and indicates its role as a proangiogenic factor. It has an association with tumor recurrence and progression. This study aims to determine the differences in VEGF expression in low-risk and highrisk meningiomas at Sanglah General Hospital, Bali, Indonesia.

Methods: This study was a cross-sectional analytical study with a sample size of 52 , which came from meningioma patients examined histopathologically at the Anatomical Pathology Laboratory of Sanglah General Hospital from January to December 2019. The VEGF immunohistochemical staining was performed and interpreted using Histo score (H-score). VEGF expression was categorized into high and low expression, with the cut-off value determined based on the median value. Data were analyzed using SPSS version 20 for Windows.

Methods: The results showed that out of 52 meningioma samples, 37 (71.1\%) cases of lowrisk meningiomas with low VEGF expression, 6 cases $(11.5 \%)$ of low-risk meningiomas with high VEGF expression, and 9 cases (17.3\%) of high-risk meningiomas with high VEGF expression. There was no high-risk meningioma with low VEGF expression. There was a significant difference in VEGF expression between the low-risk and high-risk meningioma groups ( $p=$ 0.00 ), and high VEGF expression had a prevalence risk for the incidence of high-risk meningioma by 2.5 times ( $95 \% \mathrm{Cl}=1.3-4.6)$.

Conclusion: Based on the results of this study, it was concluded that there was a VEGF expression difference between low-risk and high-risk meningiomas in Sanglah General Hospital Denpasar and high VEGF had a prevalence risk for the occurrence of high-risk meningiomas by 2.5 times.

Keywords: Meningioma, VEGF, Recurrence Risk.

Cite This Article: Sitanggang, I.J., Sriwidyani, N.P., Sumadi, I.W.J., Dewi, I.G.A.S.M., Maker, L.P.I.I., Muliarta, I.M. 2021. Perbedaan ekspresi Vascular Endothelial Growth Factor (VEGF) pada meningioma risiko rendah dan risiko tinggi di RSUP Sanglah, Bali, Indonesia. Intisari Sains Medis 12(2): 557-562. D0I: 10.15562/ism.v12i2.1027

'Departemen Patologi Anatomi, Fakultas Kedokteran, Universitas Udayana, RSUP Sanglah, Bali, Indonesia;

${ }^{2}$ Departemen Fisiologi, Fakultas Kedokteran, Universitas Udayana, Bali, Indonesia;

\section{*Korespondensi:}

Ivana Juliarty Sitanggang;

Departemen Patologi Anatomi, Fakultas Kedokteran, Universitas Udayana, RSUP Sanglah, Bali, Indonesia; ivana7arty@yahoo.com

\section{ABSTRAK}

Latar Belakang: Vascular Endothelial Growth Factor (VEGF) merupakan faktor angiogenik yang berperan penting dalam angiogenesis tumor. VEGF pada meningioma mengalami up-regulation yang menunjukkan perannya sebagai faktor proangiogenik yang berkaitan dengan rekurensi dan perkembangan tumor. Penelitian ini bertujuan untuk menentukan perbedaan ekspresi VEGF pada meningioma risiko rendah dan risiko tinggi di RSUP Sanglah, Bali, Indonesia.

Metode: Penelitian ini merupakan studi analitik potong lintang dengan besar sampel adalah 52, yang berasal dari blok parafin penderita meningioma yang diperiksa histopatologi di Laboratorium Patologi Anatomi RSUP Sanglah Denpasar dari Januari -
Desember 2019. Dilakukan pulasan imunohistokimia VEGF dan penilaiannya menggunakan Histo score (H-score). Ekspresi VEGF dikategorikan menjadi tinggi dan rendah dengan nilai cut-off yang ditentukan berdasarkan nilai median. Data dianalisis dengan SPSS versi 20 untuk Windows.

Hasil: Hasil penelitian ini menunjukkan bahwa dari 52 sampel meningioma, terdapat 37 kasus $(71,1 \%)$ meningioma risiko rendah dengan ekspresi VEGF rendah, 6 kasus (11,5\%) meningioma risiko rendah dengan ekspresi VEGF yang tinggi, dan 9 kasus (17,3\%) meningioma risiko tinggi dengan ekspresi VEGF tinggi. Tidak didapatkan meningioma risiko rendah dengan ekspresi VEGF rendah. Didapatkan perbedaan ekspresi VEGF yang bermakna antara kelompok meningioma 
risiko rendah dan risiko tinggi $(p=0,00)$ dan ekspresi VEGF tinggi mempunyai risiko prevalensi untuk terjadinya meningioma risiko tinggi sebesar 2,5 kali (95\% IK=1,3-4,6).

Kesimpulan: Berdasarkan hasil penelitian ini

Kata kunci: Meningioma, VEGF, Risiko Rekurensi.

Sitasi Artikel ini: Sitanggang, I.J., Sriwidyani, N.P., Sumadi, I.W.J., Dewi, I.G.A.S.M., Maker, L.P.I.I., Muliarta, I.M. 2021. Perbedaan ekspresi Vascular Endothelial Growth Factor (VEGF) pada meningioma risiko rendah dan risiko tinggi di RSUP Sanglah, Bali, Indonesia. Intisari Sains Medis 12(2): 557-562. D0I: 10.15562/ism.v12i2.1027

\section{PENDAHULUAN}

Meningioma merupakan tumor otak dengan kejadian yang tersering. Meskipun secara morfologi sebagian besar tumor ini jinak, namun sebagian kasus meningioma menimbulkan rekuren. Berdasarkan data yang dikumpulkan Central Brain Tumor Registry of the United States (CBTRUS) pada tahun 2014 didapatkan 67.900 kasus tumor primer otak dan susunan saraf pusat. ${ }^{1}$ Rumah Sakit Umum Pusat Sanglah tahun 2018-2019, mencatat bahwa angka kejadian meningioma menempati insiden terbanyak dari seluruh tumor otak yaitu sekitar 97 kasus (Data Sistem Informasi Manajemen Rumah Sakit/SIMARS RSUP Sanglah).

Meskipun tumor ini sebagian besar dikategorikan sebagai lesi jinak, tetapi ada variasi didalam histologi, tingkat kekambuhan, agresivitas, gejala, dan angka harapan hidup. ${ }^{1,2}$ Beberapa varian meningioma secara histologi cenderung kambuh. Secara keseluruhan grade berdasarkan WHO dapat digunakan sebagai prediktor kekambuhan. Meningioma grade I memiliki tingkat kekambuhan sekitar 7-25\%, meningioma grade II tingkat kekambuhan sekitar 29$52 \%$, dan meningioma grade III tingkat kekambuhan sekitar 50-94\%. ${ }^{2}$

Angiogenesis tergantung pada keseimbangan antara regulator angiogenik dan antiangiogenik. Vascular endothelial growth factor (VEGF) telah terbukti berperan penting dalam memicu angiogenesis pada banyak jenis kanker. ${ }^{3}$ Penghambat jalur VEGF (seperti bevacizumab) memiliki kemampuan untuk mengurangi permeabilitas pembuluh darah. Anti-VEGF cukup menjanjikan sebagai terapi yang efisien untuk perkembangan dan kekambuhan tumor otak. Biomarker VEGF dapat menjadi penanda yang sangat berguna dalam mengevaluasi aktivitas penyakit serta indikator prognosis dan keberhasilan pengobatan pada meningioma. ${ }^{3}$

Berdasarkan pada pemaparan di atas maka penelitian ini bertujuan untuk menentukan perbedaan ekspresi vascular endothelial growth factor (VEGF) pada meningioma risiko rendah dan risiko tinggi di RSUP Sanglah, Bali, Indonesia.

\section{METODE}

Penelitian ini menggunakan rancangan studi analitik potong lintang (CrossSectional) untuk mengetahui perbedaan ekspresi VEGF antara meningioma risiko rendah dan risiko tinggi. Sampel penelitian adalah pasien yang jaringan tumornya dibuat menjadi blok parafin, diperiksa secara histopatologi dan didiagnosis sebagai meningioma di Laboratorium Patologi Anatomik Fakultas Kedokteran Universitas Udayana/RSUP Sanglah Denpasar dari 1 Januari 2019 sampai 31 Desember 2019 sesuai dengan kriteria inklusi dan eksklusi. Kriteria inklusi yang dipakai yaitu pasien dengan diagnosis meningioma yang dilakukan operasi dan mengandung cukup jaringan tumor. Kriteria eksklusi yang dipakai yaitu blok parafin yang tidak cukup mengandung massa tumor atau rusak atau berjamur. Jumlah kasus yang memenuhi kriteria inklusi dan eksklusi sebanyak 52 sampel.

Preparat hasil pulasan Hematoksilin dan Eosin (HE) dilakukan pulasan imunohistokimia VEGF dengan monoclonal antibody mouse anti-human VEGF dan interpretasi ekspresi VEGF menggunakan mikroskop cahaya binokuler Olympus CX23 yang dilakukan oleh peneliti dan 2 orang spesialis Patologi Anatomi. Sel yang dinyatakan positif adalah sel tumor yang terpulas coklat pada sitoplasma sel tumor dengan intensitas lemah sampai kuat. Penilaian ekspresi VEGF dengan cara semikuantitatif menggunakan Histo score (H-score). $H$-score menghitung persentase sel dan intensitas pewarnaan yang terpulas. Intensitas pewarnaan dinilai berdasarkan empat kategori berikut: (0): tanpa pewarnaan; $(1+)$ : pewarnaan lemah; $(2+)$ : pewarnaan sedang; dan $(3+)$ : pewarnaan kuat. Histo score dihitung menggunakan rumus berikut: $1 \mathrm{x}$ (persentase pewarnaan $1+)+2 \times($ persentase pewarnaan 2+) $+3 \mathrm{x}$ (persentase pewarnaan 3+). Dari perhitungan tersebut diperoleh $\mathrm{H}$-score dengan rentang nilai 0-300 (Dabbs dan Bhargava, 2017). Ekspresi VEGF dikategorikan menjadi tinggi dan rendah dengan nilai cut-off yang ditentukan berdasarkan nilai median (Blanchard dkk., 2013). Pada penelitian ini didapatkan nilai cut-off H-score 90.

Data diolah dengan menggunakan Program Statistical Package for the Social Sciences (SPSS) 20.0 untuk Windows. Analisis deskriptif meliputi karakteristik sampel. Analisis Chi square menganalisis uji beda antara ekspresi VEGF pada meningioma risiko rendah dan risiko tinggi. Nilai batas kemaknaan (a) ditentukan pada tingkat kemaknaan $\mathrm{p}<$ 0,05 .

\section{HASIL}

Pada penelitian ini (Tabel 1) didapatkan rerata usia pasien meningioma 48,6 $\pm 9,0$ tahun, dengan rentang usia 27-77 tahun. Mayoritas kasus terdapat pada kelompok usia 41-50 tahun sebanyak 21 kasus (40,3\%). Pasien meningioma berdasarkan 
Tabel 1. Karakteristik Dasar Penderita Meningioma di RSUP Sanglah, Bali, Indonesia

\begin{tabular}{|c|c|c|}
\hline Karakteristik & Jumlah $(\mathrm{N}=52)$ & Persentase (\%) \\
\hline \multicolumn{3}{|l|}{ Usia (Tahun) } \\
\hline$<20$ & 0 & 0 \\
\hline $21-30$ & 1 & 1,9 \\
\hline $31-40$ & 9 & 17,3 \\
\hline $41-50$ & 21 & 40,3 \\
\hline $51-60$ & 16 & 30,7 \\
\hline $61-70$ & 4 & 7,7 \\
\hline $71-80$ & 1 & 1,9 \\
\hline \multicolumn{3}{|l|}{ Jenis Kelamin } \\
\hline Perempuan & 47 & 90,4 \\
\hline Laki-laki & 5 & 9,6 \\
\hline \multicolumn{3}{|l|}{ Supratentorial } \\
\hline Parietal & 4 & 7,6 \\
\hline Frontal & 10 & 19,2 \\
\hline Temporal & 7 & 13,4 \\
\hline Temporoparietal & 3 & 5,7 \\
\hline Frontoparietal & 1 & 1,9 \\
\hline Sphenoid & 6 & 11,5 \\
\hline Parasagital & 8 & 15,3 \\
\hline Suprasella & 2 & 3,8 \\
\hline Occipital & 3 & 5,7 \\
\hline Olfactory grooves & 1 & 1,9 \\
\hline Thalamus & 1 & 1,9 \\
\hline \multicolumn{3}{|l|}{ Infratentorial } \\
\hline Medulla spinalis & 6 & 11,5 \\
\hline \multicolumn{3}{|l|}{ Risiko Rendah } \\
\hline Meningothelial & 9 & 17,3 \\
\hline Fibrous (fibroblastic) & 10 & 19,2 \\
\hline Transitional & 15 & 28,8 \\
\hline Psammomatous & 3 & 5,7 \\
\hline Angiomatous & 4 & 7,6 \\
\hline Microcystic & 1 & 1,9 \\
\hline Secretory & 0 & 0 \\
\hline Lymphoplasmacyte-rich & 0 & 0 \\
\hline Metaplastic & 1 & 1,9 \\
\hline \multicolumn{3}{|l|}{ Risiko Tinggi } \\
\hline Chordoid & 0 & 0 \\
\hline Clear cell & 0 & 0 \\
\hline Atypical & 8 & 15,4 \\
\hline Papillary & 0 & 0 \\
\hline Rhabdoid & 0 & 0 \\
\hline Anaplastic & 1 & 1,9 \\
\hline
\end{tabular}

jenis kelamin didominasi oleh perempuan sebesar 47 kasus $(90,4 \%)$ sementara lakilaki hanya sebesar 5 kasus (9,6\%). Lokasi dari meningioma pada penelitian ini (Tabel 1) paling banyak ditemukan pada daerah supratentorial yaitu 46 kasus $(88,5 \%)$, dimana lokasi frontal mendominasi pada daerah ini yaitu sebesar 10 kasus $(21,7$ $\%)$, sementara daerah infratentorial hanya 6 kasus (11,5\%) pada medulla spinalis (Tabel 1).

Distribusi frekuensi seluruh sampel penderita meningioma berdasarkan subtipe histopatologi dapat dilihat pada Tabel 2. Jumlah kasus untuk tipe histologi yang termasuk meningioma risiko rendah 43 kasus (82,7\%), sedangkan risiko tinggi 9 kasus (17,3\%). Distribusi frekuensi seluruh sampel penderita meningioma berdasarkan grading histologi dapat dilihat pada Tabel 2. Kasus yang termasuk menigioma risiko rendah (grade I) sebesar $82,7 \%$, sedangkan kasus yang termasuk risiko tinggi (grade II dan III) 17,3 \%

Pada penelitian ini juga dapat (Tabel 2). dilihat distribusi usia dan jenis kelamin penderita meningioma berdasarkan grading histologi yang tersaji pada Tabel 3. Jumlah kasus risiko rendah (grade I) terlihat paling banyak pada kelompok usia 41-50 tahun sebesar 18 kasus (40,4\%), sedangkan risiko tinggi (grade II dan III) pada kelompok usia 51-60 tahun sebesar 4 kasus (44,4\%). Perempuan lebih banyak mendominasi pada kasus meningioma grade I sebanyak 39 kasus (90,6\%), dan pada meningioma grade II dan III perempuan juga mendominasi sebesar 8 kasus $(88,8 \%)$ (Tabel 3).

Gambaran ekspresi VEGF disajikan dalam Gambar 1. Ekspresi VEGF pada penelitian ini dikategorikan rendah dan tinggi dengan cut-off didapatkan dengan median $\mathrm{H}$-score yaitu 90, bila lebih rendah dari 90 maka dikategorikan ekspresi VEGF yang rendah dan $\mathrm{H}$-score diatas atau sama dengan 90 maka dikategorikan ekspresi VEGF yang tinggi. Perhitungan statistik ekspresi VEGF pada meningioma risiko rendah dan risiko tinggi dengan uji ChiSquare menunjukkan terdapat perbedaan nilai $\mathrm{H}$-Score yang bermakna $(\mathrm{p}<0,01)$ $(\mathrm{OR}=2,5 ; 95 \% \mathrm{IK}=1,3-4,6)$ (Tabel 4).

\section{PEMBAHASAN}

Pada penelitian ini yang didominasi oleh perempuan sebesar $90,4 \%$ dan sisanya adalah laki-laki. Penelitian yang dilakukan oleh Dolecek TA et al., dan Grujicic D et al., memaparkan hal yang sama yaitu insidensi pria:wanita sebesar 1:9.,5 Tingginya angka kejadian pada perempuan, tampaknya faktor hormonal berperan pada tumorigenesis meningioma. ${ }^{6}$ Hubungan antara hormon jenis kelamin dan risiko meningioma telah dinyatakan pada sejumlah temuan termasuk peningkatan insidensi penyakit setelah pubertas pada wanita dibandingkan pria dengan rasio tertinggi 3,15:1 selama tahun puncak reproduktif. Keberadaan reseptor estrogen, reseptor progesteron, dan reseptor androgen ditemukan pada beberapa meningioma dan adanya studi mengenai kejadian regresi meningioma multipel pada pasien setelah penghentian terapi agonis estrogen. ${ }^{7}$ Beberapa mekanisme biologis menjelaskan bagaimana hormon wanita dapat meningkatkan risiko terjadinya meningioma. Hormon wanita dapat memodulasi proliferasi 
dan perkembangan siklus sel melalui mekanisme transkripsi yang melibatkan reseptor. Estrogen telah ditetapkan sebagai hormon yang ketidakstabilan genom dari sel. Sebagai tambahan, estrogen juga berinteraksi dengan insulin growth factor (IGF), yang merangsang pertumbuhan tumor dan mencegah apoptosis sel. ${ }^{8}$

Meningioma merupakan tumor dengan pertumbuhan yang lambat yang banyak menyerang usia separuh baya hingga lanjut usia dengan insiden puncak dekade keenam hingga ketujuh., ${ }^{9,10}$ Pada penelitian ini sebagian besar penderita meningioma terjadi pada kelompok usia 46-55 tahun. Hal ini sejalan seperti penelitian meningioma yang dilakukan di beberapa negara oleh. ${ }^{11}$ Hampir semua sampel penelitian ini menunjukkan lokasi meningioma pada daerah intrakranial. Mayoritas lokasi tumor dalam penelitian ini yaitu sebesar $96,1 \%$ terletak supretentorial sementara daerah infratentorial hanya 19,2\%. Secara umum, convexity merupakan lokasi yang tersering $(96,1 \%)$ dimana frontal dan parasagital menjadi lokasi yang paling dominan dalam kelompok ini. Hal ini sama seperti penelitian-penelitian yang dilaporkan. ${ }^{12}$

Dari semua studi meningioma yang telah terpublikasi, semua kasus meningioma menunjukkan mayoritas adalah grade I disusul oleh grade II dan grade III sebagai kasus yang paling sedikit. ${ }^{13}$ Sama halnya yang terjadi pada penelitian ini, sebesar $82,6 \%$ terdiri dari meningioma grade I, 15,3\% untuk grade II, dan 1,3\% untuk grade III.

Secara keseluruhan meningioma terdiri dari 15 subtipe histopatologi yang terbagi atas 9 subtipe untuk grade 1 dan 3 subtipe untuk masing-masing grade 2

Tabel 2. Karakteristik Penderita Meningioma Berdasarkan Grading Histologi dan Risiko Rekurensi di RSUP Sanglah, Bali, Indonesia

\begin{tabular}{ccccc}
\hline Kategori Risiko & Grading Histologi & $\begin{array}{c}\text { Jumlah } \\
\text { (n=52) }\end{array}$ & $\begin{array}{c}\text { Persentase } \\
\text { (\%) }\end{array}$ & Total (\%) \\
\hline Risiko Rendah & Grade I & 43 & 82,7 & 82,7 \\
Risiko Tinggi & Grade II & 8 & 15,4 & 17,3 \\
& Grade III & 1 & 1,9 & \\
\hline
\end{tabular}

Tabel 3. Karakteristik Usia dan Jenis Kelamin Berdasarkan Kategori Risiko Rekurensi dan Agresifitas Tumor di RSUP Sanglah, Bali, Indonesia

\begin{tabular}{lcccc}
\hline \multirow{2}{*}{ Karakteristik } & \multicolumn{2}{c}{ Risiko Rendah (grade I) } & \multicolumn{2}{c}{$\begin{array}{c}\text { Risiko Tinggi } \\
\text { (grade II dan III) }\end{array}$} \\
\cline { 2 - 5 } & $\mathbf{N}=\mathbf{4 3}$ & $\%$ & $\mathbf{N}=\mathbf{9}$ & $\%$ \\
\hline Usia (Tahun) & & & & \\
$<20$ & 0 & 0,0 & 0 & 0,0 \\
$21-30$ & 1 & 2,3 & 0 & 0,0 \\
$31-40$ & 9 & 21,4 & 0 & 0,0 \\
$41-50$ & 18 & 40,4 & 3 & 33,3 \\
$51-60$ & 12 & 28,6 & 4 & 44,4 \\
$61-70$ & 2 & 4,7 & 2 & 22,4 \\
$71-80$ & 1 & 2,3 & 0 & 0,0 \\
Jenis Kelamin & & & & 88,8 \\
Perempuan & 39 & 90,6 & 8 & 11,1 \\
Laki-laki & 4 & 9,3 & 1 & \\
\hline
\end{tabular}

dan 3. Akan tetapi tidak semua subtipe dapat dijumpai pada penelitian ini dikarenakan karena terdapat beberapa subtipe yang memang merupakan jenis yang jarang ditemukan. Transitional meningioma WHO grade I merupakan subtipe yang paling banyak dijumpai pada penelitian ini sebesar 30,7\% diikuti fibrous (fibroblastic) meningioma WHO grade I sebanyak 19,2\%. Beberapa studi memberikan gambaran yang hampir sama dengan penelitian ini seperti Reszec, dkk., sebanyak 66,6\% kasus merupakan transitional meningioma dan fibrous (fibroblastic) meningioma sebagai meningioma tersering kedua sebesar $10,7 \%{ }^{14}$ Jungwirth $G$ et al., mencatat $48 \%$ dan $28 \%$ sebagai transitional meningioma dan fibrous (fibroblastic) meningioma. ${ }^{15}$ Shahin $\mathrm{MN}$ et al., dan Hui $\mathrm{M}$ et al., melaporkan masing-masing $20 \%$ dan 6,6\% untuk kasus transitional dan fibrous (fibroblastic) meningioma sebagai subtipe tersering pada penelitian mereka. ${ }^{16,17}$ Sedikit berbeda terhadap studi Hua L et al., dimana fibrous (fibroblastic) meningioma sebagai mayoritas kasus $(37,27 \%)$ yang diikuti meningothelial meningioma $(26,5 \%)$ sebagai terbanyak kedua. Semua subtipe meningioma grade II dapat dijumpai pada penelitian saat ini dengan atypical meningioma sebagai kasus terbanyak 9,4\% kasus. Sementara untuk meningioma grade III hanya subtipe anaplastic meningioma yang ditemukan. ${ }^{18} \mathrm{Hal}$ ini serupa dengan yang diutarakan Okuchi, dkk. bahwa atypical meningioma dengan persentase 17,8\% merupakan subtipe terbanyak untuk meningioma grade II namun untuk grade III subtipe anaplastic meningioma lebih sering dijumpai (1,7\%). Okuchi, S et al., juga melaporkan atypical meningioma sebagai subtipe terbanyak untuk grade II bahkan dengan persentase yang jauh lebih tinggi dibandingkan penelitian ini yaitu sebesar $100 \%$ dan anaplastic meningioma

Tabel 4. Distribusi ekspresi VEGF berdasarkan grade meningioma

\begin{tabular}{ccccccc}
\hline \multirow{2}{*}{ H-Score VEGF } & \multicolumn{2}{c}{ Grading Meningioma (N=52) } & & Total & OR & 95\% IK \\
\cline { 2 - 5 } & $\begin{array}{c}\text { Risiko Rendah } \\
\text { (Grade I) } \mathbf{( N = 4 3 )}\end{array}$ & $\begin{array}{c}\text { Risiko Ting } \\
\text { (Grade II dan III) (N=9) }\end{array}$ & $0(0,0)$ & 37 & 2,5 & $1,3-4,6$ \\
\hline Rendah $(<90), \mathrm{n}(\%)$ & $37(86,1)$ & $9(100,0)$ & 15 & $<0,01^{\star}$ \\
Tinggi $(\geq 90), \mathrm{n}(\%)$ & $6(13,9)$ & & & \\
\hline
\end{tabular}

VEGF: Vascular Endothelial Growth Factor; OR: Odds: Ratio; IK: Interval Kepercayaan; ${ }^{\star}$ Secara statistik bermakna apabila nilai-p kurang dari 0,05 pada uji Chi-Square 

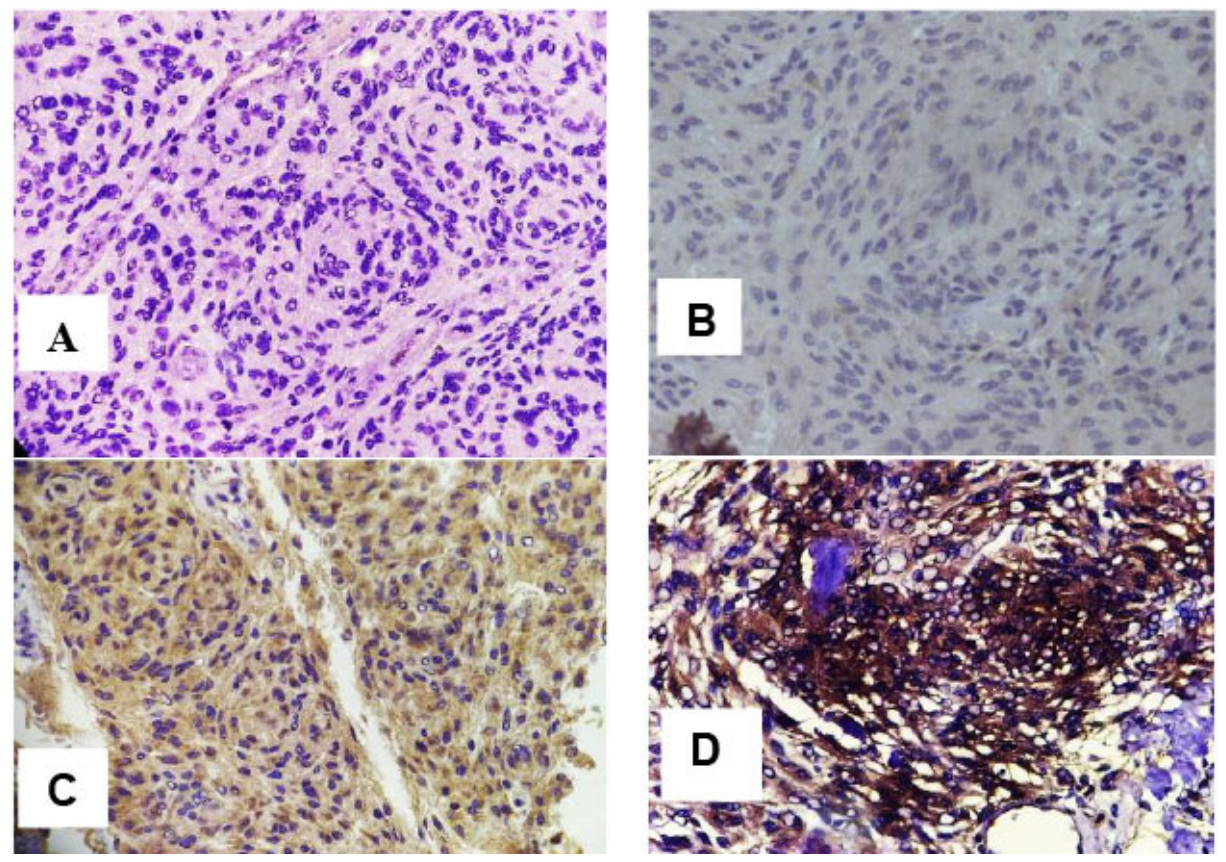

Gambar 1. Ekspresi VEGF pada meningioma. (A) Kasus meningioma meningothelial grade I dengan ekspresi VEGF negatif; (B) Kasus meningioma transitional grade I dengan ekspresi VEGF lemah; (C) Kasus meningioma meningothelial grade I dengan ekspresi VEGF sedang; (D) Kasus meningioma atypical grade II dengan ekspresi VEGF kuat (Imunohistokimia dengan pembesaran 400 kali).

merupakan satu-satunya subtipe yang dijumpai untuk meningioma grade III. ${ }^{19}$

Hasil penelitian ini didapatkan perbedaan ekspresi VEGF yang bermakna antara kelompok meningioma risiko rendah dan risiko tinggi. Namun menariknya terdapat ekspresi VEGF yang berbeda diantara subtipe histologi dalam kelompok risiko rendah, dimana ada dari kelompok meningioma risiko rendah didapatkan ekspresi VEGF yang tinggi yaitu 4 kasus subtipe meningioma angiomatous kemudian disusul oleh 2 kasus transitional meningioma dan 1 fibrous (fibroblastic). Hal ini serupa dengan yang diutarakan Mahzouni P et al., didapatkan 1 kasus angiomatous meningioma, 1 kasus fibrous (fibroblastic) meningioma dan 2 kasus transitional meningioma. ${ }^{3}$

Meningioma angiomatous didapatkan ekspresi VEGF yang sangat tinggi disebabkan karena sifat alami dari subtipe ini. Ekspresi VEGF pada meningioma transitional mirip dengan kelompok meningioma risiko tinggi sedangkan ekspresi VEGF pada subtipe fibroblastic lebih sedikit. Hasil penelitian ini sesuai dengan penelitian yang dilakukan
Mahzouni P et al. ${ }^{3}$ Dengan demikian jelas bahwa potensi angiogenik meningioma merupakan karakteristik subtipe histologis dan tidak ditentukan oleh grade meningioma.

\section{SIMPULAN}

Berdasarkan hasil penelitian ini dapat disimpulkan bahwa terdapat perbedaan ekspresi VEGF antara meningioma risiko rendah dan risiko tinggi di RSUP Sanglah, Bali, Indonesia. VEGF tinggi mempunyai risiko prevalensi untuk terjadinya meningioma risiko rekurensi tinggi sebesar 2,5 kali.

\section{KONFLIK KEPENTINGAN}

Penulis menyatakan tidak terdapat konflik kepentingan terkait publikasi dari penelitian ini.

\section{ETIKA PENELITIAN}

Penelitian ini telah mendapatkan persetujuan dari Komite Etik Fakultas Kedokteran Universitas Udayana/RSUP Sanglah Denpasar dengan No. 820/UN
14.2.2.VII.14/LT/2020.

\section{PENDANAAN}

Penelitian ini tidak mendapatkan bantuan dana hibah dari pemerintah maupun sektor swasta lainnya.

\section{KONTRIBUSI PENELITIAN}

Seluruh penulis memiliki kontribusi yang sama dalam laporan penelitian ini baik dari penyusunan kerangka konsep, pengumpulan data, analisis data, hingga interpretasi hasil penelitian dalam bentuk publikasi ilmiah.

\section{DAFTAR PUSTAKA}

1. Ostrom QT, Patil N, Cioff G, Waite K, Kruchko C, Barnholtz-Sloan JS. CBTRUS Statistical Report: Primary Brain and Other Central Nervous System Tumors Diagnosed in the United States in 2013-2017. Neuro Oncol. 2020;22(12 Suppl 2):iv1-iv96.

2. Komori T. The 2016 WHO Classification of Tumours of the Central Nervous System: The Major Points of Revision. Neurol Med Chir (Tokyo). 2017;57(7):301-311.

3. Mahzouni P, Aghili E, Sabaghi B. An Immunohistochemical Study of Vascular Endothelial Growth Factor Expression in Meningioma and Its Correlation with Tumor Grade. Middle East Journal of Cancer. 2018;9(4):288-294.

4. Dolecek TA, Dressler EV, Thakkar JP, Liu M, Al-Qaisi A, Villano JL. Epidemiology of meningiomas post-Public Law 107-206: The Benign Brain Tumor Cancer Registries Amendment Act. Cancer. 2015;121(14):24002410.

5. Grujicic D, Cavallo LM, Somma T, Illic R, Milicevic M, Raicevic S, et al. Intraventricular Meningiomas: A Series of 42 Patients at a Single Institution and Literature Review. World Neurosurg. 2017;97:178-188.

6. Korhonen K, Salminen T, Raitanen J, Auvinen A, Isola J, Haapasalo H. Female predominance in meningiomas can not be explained by differences in progesterone, estrogen, or androgen receptor expression. J Neurooncol. 2006;80(1):1-7.

7. Wiemels J, Wrensch M, Claus EB. Epidemiology and etiology of meningioma. J Neurooncol. 2010;99(3):307-314.

8. Qi ZY, Shao C, Huang YL, Hui GZ, Zhou YX, Wang Z. Reproductive and exogenous hormone factors in relation to risk of meningioma in women: a meta-analysis. PLoS One. 2013;8(12):e83261.

9. Champeaux C, Dunn L. World Health Organization Grade II Meningioma: A 10Year Retrospective Study for Recurrence and Prognostic Factor Assessment. World Neurosurg. 2016;89:180-186.

10. Buerki RA, Horbinski CM, Kruser T, Horowitz PM, James CD, Lukas RV. An overview of 
meningiomas. Future Oncol. 2018;14(21):21612177.

11. Jensen R, Lee J. Predicting outcomes of patients with intracranial meningiomas using molecular markers of hypoxia, vascularity, and proliferation. Neurosurgery. 2012;71(1):146156.

12. Laksmi SS. Meningiomas: A Clinicopathological Study. Int J Med Res Health Sci. 2015;4(4):82731.

13. Yang CC, Tsai C, Chen SJ, Chiang MF, Lin JF, Hu $\mathrm{CK}$, et al. Factors Associated with Recurrence of Intracranial Meningiomas After Surgical Resection: A Retrospective Single-Center Study. International Journal of Gerontology. 2018;12(1):57-61.

14. Reszec J, Hermanowicz A, Rutkowski R, Turek G, Mariak Z, Chyczewski L. Expression of MMP-9 and VEGF in meningiomas and their correlation with peritumoral brain edema. Biomed Res Int. 2015;2015:646853.

15. Jungwirth G, Warta R, Beynon C, Sahm F, von Deimling A, Unterberg A, et al. Intraventricular meningiomas frequently harbor NF2 mutations but lack common genetic alterations in TRAF7, AKT1, SMO, KLF4, PIK3CA, and TERT. Acta Neuropathol Commun. 2019;7(1):140.

16. Shahin MN, Magill ST, Dalle Ore CL, Viner JA, Peters PN, Solomon DA, et al. Fertility treatment is associated with multiple meningiomas and younger age at diagnosis. J Neurooncol. 2019 May;143(1):137-144.

17. Hui M, Uppin MS, Saradhi MV, Sahu BP, Purohit AK, Sundaram C. Pediatric meningiomas an aggressive subset: a clinicopathological and immunohistochemical study. J Postgrad Med. 2015;61(1):32-35
18. Hua L, Zhu H, Deng J, Tian M, Jiang X, Tang $\mathrm{H}$, et al. Clinical and prognostic features of spinal meningioma: a thorough analysis from a single neurosurgical center. J Neurooncol. 2018;140(3):639-647.

19. Okuchi S, Okada T, Yamamoto A, Kanagaki M, Fushimi Y, Okada T, et al. Grading meningioma: a comparative study of thalliumSPECT and FDG-PET. Medicine (Baltimore). 2015;94(6):e549.

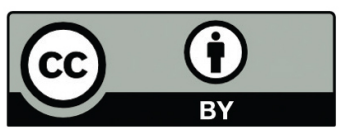

This work is licensed under a Creative Commons Attribution 